Original article

\title{
A New Approach to Maggot Therapy for Healing of Diabetic Foot Ulcers
}

\author{
Omid Dehghan ${ }^{1}$, Seyed Mehdi Tabaie², Javad Rafinejad ${ }^{1}$, Mehrangiz Toutonnchy², \\ Amir Tiyuri ${ }^{3}$, Kamran Akbarzadeh ${ }^{4}$, Seyed Farzad Motevalli Haghi ${ }^{5}$ \\ ${ }^{1}$ Department of Medical Entomology and Vector Control, School of Public Health, \\ Tehran University of Medical Sciences, Tehran, Iran \\ ${ }^{2}$ Department of Dermatology, Medical Laser Research Center, ACECR, Tehran, Iran \\ ${ }^{3}$ Department of Epidemiology, School of Health, Iran University of Medical Sciences, Tehran, Iran \\ ${ }^{4}$ Department of Medical Entomology and Vector Control, School of Public Health, \\ Tehran University of Medical Sciences, Tehran, Iran \\ ${ }^{5}$ Department of Medical Entomology and Vector Control, Health Sciences Research Center, Addiction Institute, \\ Faculty of Health, Mazandaran University of Medical Sciences, Mazandaran (Sari), Iran
}

\section{SUMMARY}

The use of maggot therapy (MT) is proving effective in the treatment of complicated diabetic foot ulcers (DFUs). Most of the previous studies have focused on the comparison of MT and routine treatment approaches for the management of DFUs. The aim of this study was to add MT to routine treatment line of DFUs as a new approach. In this study, the principal expectation from MT method was to prepare wound bed for continuation of the treatment with other measures. This study was designed as a before-after observational study. Twenty-five out of the initial 47 volunteers who presented with DFUs to our wound clinic were included in our study. In the present study, a total of 27 DFU cases were managed with maggot therapy using the Karaj Strain of Lucilia sericata (L. sericata). MT was added to routine treatments as a complementary therapy. Surface areas of the necrotic tissues and granulation tissues over time were calculated. Satisfaction of patients and physicians was evaluated with a questionnaire. There was a significant reduction in the surface area of necrotic tissues and increase in the surface area of granulation tissues $(p<$ 0.0001 ) as early as four days after the initiation of maggot therapy. After adjusting for confounding variables, statistical analysis confirmed a significant reduction in the size of necrotic tissues and increase in granulation tissues formation $(p<0.001)$. About $96.3 \%$ of the physicians and patients involved in our study were satisfied with the results of the treatment. The time for significant reduction of the size of necrotic tissues was less than in similar studies. This study confirmed that effective, faster and satisfactory results can be achieved when MT is added to routine treatments as a complementary therapy for healing DFUs. This approach can be introduced as a new treatment modality for healing DFUs with high rate success.

Key words: maggot therapy, diabetic foot ulcers, Lucilia sericata

Corresponding author:

Kamran Akbarzadeh

e-mail: kamran.akbarzadeh@yahoo.com 


\section{INTRODUCTION}

According to recent reports, about 422 million adults lived with diabetes in 2014 (1). One of the major complications of diabetes is non-healing foot ulcers, which frequently leads to lower extremity amputation. Over the past decade, the rate of amputation ranged from 1.5 to 3.5 events per 1,000 confirmed diabetic patients annually. Some high income countries have reported a $40-60 \%$ reduction in the rate of amputation during the last $10-15$ years, however, such data do not exist for low or moderate income countries (2).

Diabetic foot ulcers (DFUs) stand for a very complicated condition due to blood vessel disorders, high load of bacterial flora and biofilms, and resistance to antibiotics. These factors increase necrotic tissue formation and delayed wound healing (3), representing a major challenge to various treatment approaches for healing DFUs. The routine treatment modalities for DFUs are associated with limited efficacy, need for anaesthesia, pain, and mechanical damage to the underlying healthy tissues (4). One treatment protocol which proves effective in overcoming complicated conditions of DFUs is the use of maggot therapy (5).

Effectiveness of Lucilia sericata (Diptera: Calliphoridae) as the agent for maggot therapy for the removal of necrotic tissue (debridement), disinfection, rapid elimination of infecting microorganisms, and enhancement of the healing process of DFUs has been proven (6). The use of maggots as medicinal agents is an ancient practice and the oldest documents related to maggot therapy were recorded in the $16^{\text {th }}$ century (7). A new approach to modern maggot therapy re-emerged during the 1980s (8).

Following the successful use of this method in various parts of the world, especially in the US and some European countries, the FDA has approved the use of the larvae of L. sericata as medicinal devices (9). There is one documented report on the use of maggot therapy in Iran for the management of DFUs (10) and plenty of other studies conducted in differ- ent countries, but most of these studies tried to compare the efficacy of maggot therapy with routine modern therapies and sharp debridement.

The wound preparation is important for wound management especially for the hard-to-heal wounds (11). This process has been mentioned as one of the best result of the MDT (12). The hypothesis for new approach in this study was to show the effectiveness of MDT for preparing the granulated wound bed in wounds along with other conventional healing measures. Therefore, the aim of this study was to introduce a new approach to maggot therapy as a complimentary therapy to other routine treatment protocols of DFUs.

Some limitations in the use of maggot therapy and patients and physicians dissatisfaction due to the need for continuous and long-term application require new approach to maggot therapy, particularly as a complimentary therapy along with other routine therapeutic methods. Satisfaction of patients and approval by the clinical team can affect the introduction of new approaches to treatment protocols. In the modern medical practice, decisions are based on evidence-based protocols (13). A literature review indicated that patient's satisfaction may be much more important in treatment protocols of diabetes (14). Satisfaction of patients and physicians with maggot therapy for the treatment of DFUs was assessed in this study with a questionnaire.

\section{PARTICIPANTS AND METHODS}

This study was designed as a before-after observational study. Twenty-five volunteers who presented with 27 DFUs to the wound treatment clinic, ACECR, of Tehran University of Medical Sciences (TUMS) were involved in our study (Figure 1). All the wounds were categorized as grade 2 DFUs based on the Wagner Ulcer classification (15).

Inclusion criteria for our study included the following: patients who have at least one DFU, without a history of entomophobia, alcohol or opium abuse, and had signed the informed consent. Patients who appeared to have severe pains, bleeding, 


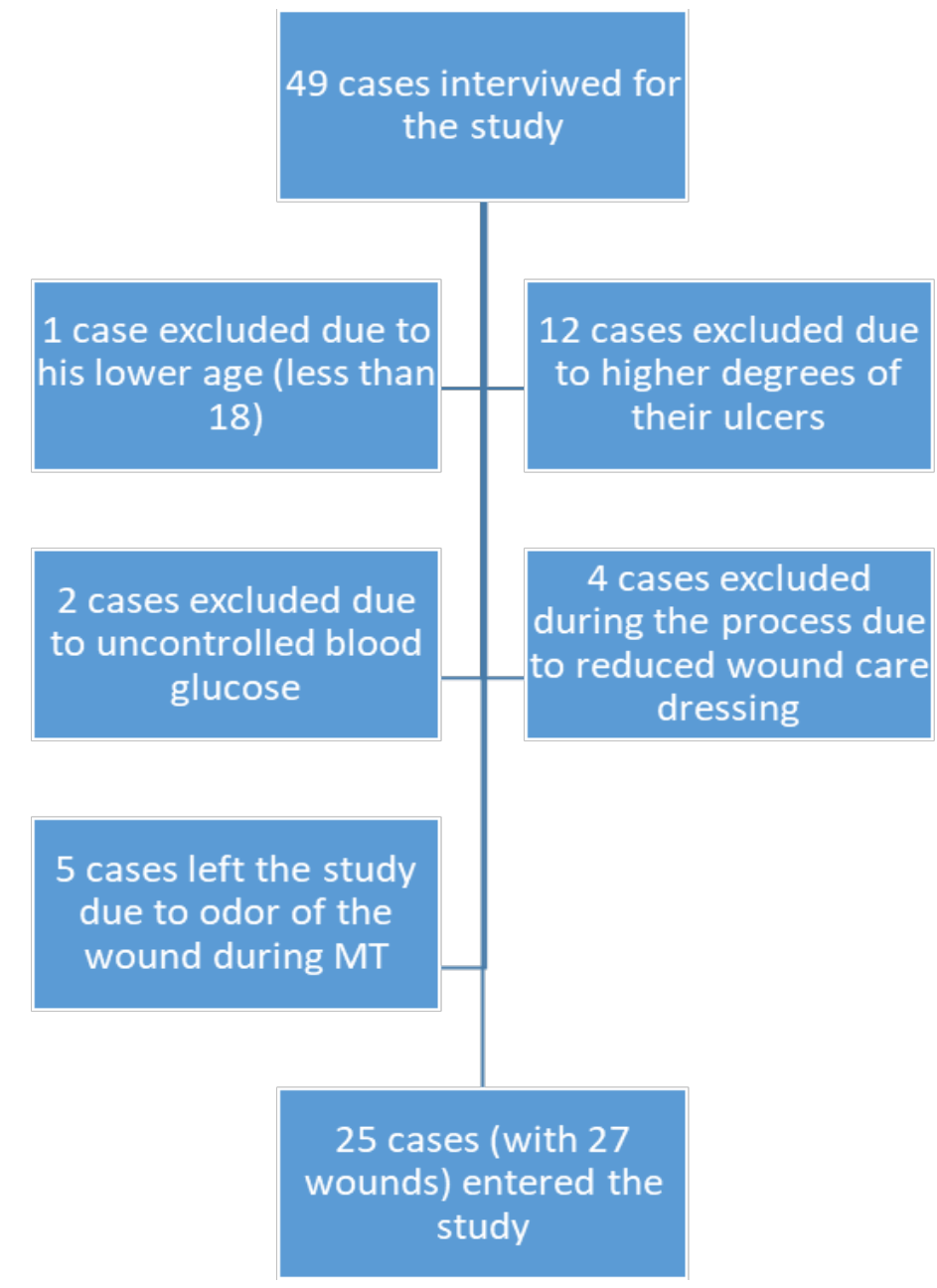

Figure 1. A diagram of the interviewed, excluded and included cases in the study

mental disorders, and special unexpected situations leading to hospitalization were excluded from the study. Immunocompromised patients other than diabetics, like HIV/AIDS patients, were also excluded from the study. For better application of maggot therapy, hard-to-heal wounds were selected.

The Karaj Strain of L. sericata was used for the maggot therapy in this study. Sterile larvae of $L$. sericata were prepared and stored at the laboratory of therapeutic flies, Tehran University of Medical Sciences.

Maggots were applied directly onto the wound at a dose of 8 - 10 L1 instar maggots per 1 $\mathrm{cm}^{2}$ of wound surface. Special dressing was placed over the wound to prepare a place like a small cage for the activities of the larvae. The method for wound dressing was somehow similar to that of Gottrup and Jørgensen (16). Maggots were re-applied every 48 hours. Alongside the maggot therapy, patients underwent routine DFU treatment in- cluding sharp debridement, antibiotic therapy, ozon therapy, vacume therapy and new dressings such as silver dressings. Routine treatment differed due to the wounds. Maggot therapy was added to the routine treatment as a complementary therapy.

Indication of wound bed preparation in this study was to calculate the surface areas of necrotic tissues and granulation tissues which were photographed and analyzed by Matlab 6.1 Software ${ }^{\circledR}$ before and after treatment. To minimize errors in the calculation of wound surface area, the photography and software analyses were repeated three times for each DFU.

Statistical analyses were performed using ANCOVA and Wilcoxson in SPSS 18 software ${ }^{\circledR}$. Similar to the criteria used by some other scientists (17), reduction in the size of necrotic tissues and appearance or extent of granulation tissue formation were the main factors used for the evaluation of maggot therapy in this study. 


\section{RESULTS}

The patients in our study included $13(52 \%)$ males and $12(48 \%)$ females. The average age of the patients was $59.7 \pm 11.5$ years. Patients had a history of $17.7 \pm 10.1$ years of diagnosed diabetes and $10.3 \pm$ 13.8 months of DFUs.
In this study, a wide variety of other routine healing procedures (summarized in Table 1) were involved in the management of the 27 wounds in addition to the maggot therapy.

Patients received maggot therapy for an average of $2.8 \pm 1.6$ days. Based on Wilcoxon analysis, there was a significant difference $(p<0.0001)$

Table 1. Other routine healing procedures applied together with maggot therapy. ACECR, 2017.

\begin{tabular}{c|c|c|c|c|c|c}
\hline \hline $\begin{array}{c}\text { Medical } \\
\text { intervention }\end{array}$ & $\begin{array}{c}\text { Sharp } \\
\text { debridement }\end{array}$ & $\begin{array}{c}\text { Ozone } \\
\text { therapy }\end{array}$ & PRP & $\begin{array}{c}\text { Silver } \\
\text { dressings }\end{array}$ & $\begin{array}{c}\text { Injectable } \\
\text { antibiotics }\end{array}$ & $\begin{array}{c}\text { Oral } \\
\text { antibiotics }\end{array}$ \\
\hline $\begin{array}{c}\text { Number of } \\
\text { wounds }\end{array}$ & 27 & 11 & 9 & 13 & 9 & \\
\hline \hline
\end{tabular}

Table 2. The mean scores of the surface area of necrotic tissue before and after maggot therapy in the study participants, based on ANCOVA results. ACECR, 2017.

\begin{tabular}{l|c|c|c|c|c}
\hline \hline Variable & Sum of squares & Degree of freedom & Mean Square & F & P-value \\
\hline Intercept & 1.6 & 1 & 1.6 & 4.6 & .045 \\
\hline Before necrotic space & 8.15 & 1 & 8.15 & 24.2 & $<0.001$ \\
\hline Gender & .17 & 1 & .17 & .52 & .48 \\
\hline Days of intervention & 22.38 & 2 & 11.2 & 33.3 & .000 \\
\hline Age & .633 & 1 & .633 & 1.88 & .19 \\
\hline Duration of ulcer & .041 & 1 & .041 & .121 & .73 \\
\hline History of diabetes & .044 & 1 & .044 & .129 & .72 \\
\hline Error & 6.4 & 19 & .336 & & \\
\hline Total & 171.2 & 27 & & & \\
\hline \hline
\end{tabular}

Table 3. The mean scores of the surface area of granulation tissue formed in the wounds before and after maggot therapy in the study participants, based on ANCOVA results. ACECR, 2017.

\begin{tabular}{l|c|c|c|c|c}
\hline \hline Variable & Sum of squares & Degree of freedom & Mean Square & F & P-value \\
\hline Intercept & .154 & 1 & .154 & .060 & .81 \\
\hline Before granular space & 44.05 & 1 & 44.05 & 17.2 & .001 \\
\hline Gender & 1.41 & 1 & 1.41 & .55 & .47 \\
\hline Days of intervention & 8.92 & 2 & 4.46 & 1.74 & .20 \\
\hline Age & 1.68 & 1 & 1.68 & .65 & .43 \\
\hline Duration of ulcer & 1.37 & 1 & 1.37 & .54 & .47 \\
\hline History of diabetes & 6.62 & 1 & 6.62 & 2.59 & .12 \\
\hline Error & 48.7 & 19 & 2.56 & & \\
\hline Total & 647.8 & 27 & & & \\
\hline \hline
\end{tabular}


between the average surface area of necrotic tissue before $\left(3.51 \pm 2.6 \mathrm{~cm}^{2}\right)$ and after treatments $(2.35 \pm$ $\left.0.99 \mathrm{~cm}^{2}\right)$. Wilcoxon analysis also showed a significant increase $(p<0.0001)$ in the surface area of granulation tissue before $(1.52 \pm 0.96)$ and after treatment $(4.1 \pm 2.78)$.

Effects of confounding variables such as age, gender, duration of diabetes, duration of wounds, and duration of maggot therapy on the results were evaluated using ANCOVA. After adjusting for the con- founding variables, ANCOVA analysis confirmed a significant reduction in the size of necrotic tissues and increase in the size of granulation tissues $(\mathrm{p}<0.001)$ (Table 2 and 3). All of the cases were neuropathic diabetic foot ulcer and in their history clearly had the features of hard-to-heal wounds. Photos of four successfully treated cases are shown in Figures $2-5$ as representative to point out the effectiveness of the new approach of maggot therapy with other routine treatment procedures.
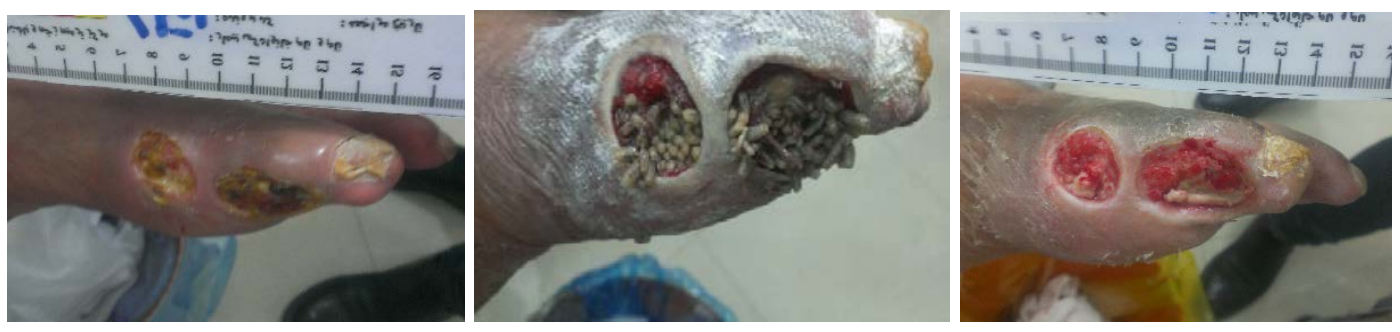

Figure 2. Diabetic foot ulcers in the right leg of a 40-year-old female, which have been treated with three rounds of maggot therapy in ACECR, Tehran, Iran (Original photos)
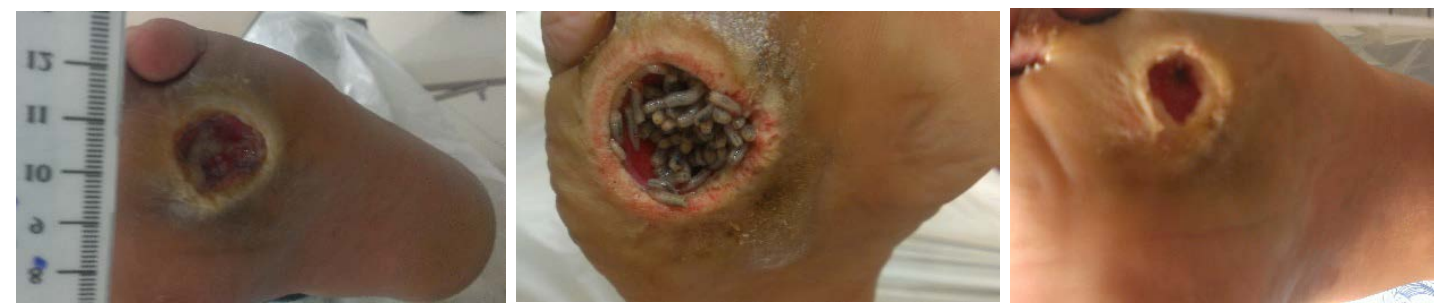

Figure 3. Diabetic foot ulcers in the right leg of a 37-year-old male, which have been treated with two rounds of maggot therapy in ACECR, Tehran, Iran (Original photos)
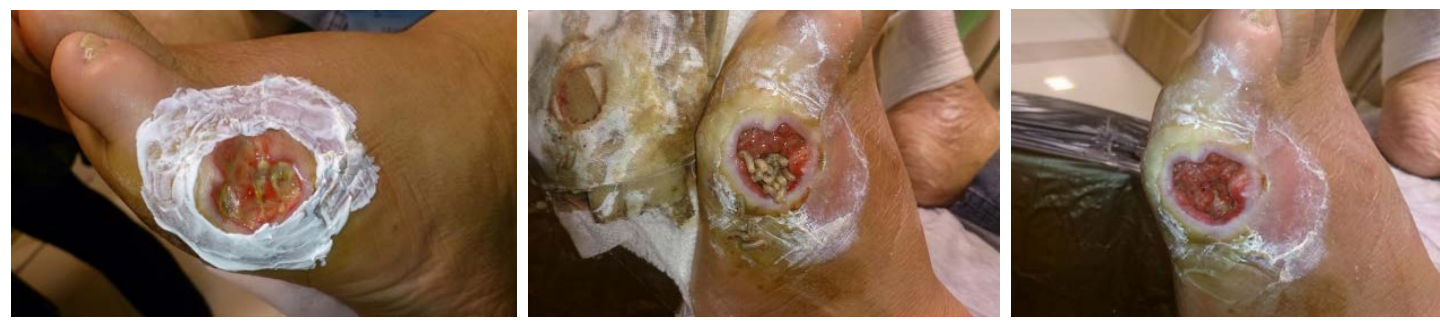

Figure 4. Diabetic foot ulcers in the right leg of a 45-year-old female, which have been treated with two rounds of maggot therapy in ACECR, Tehran, Iran (Original photos)
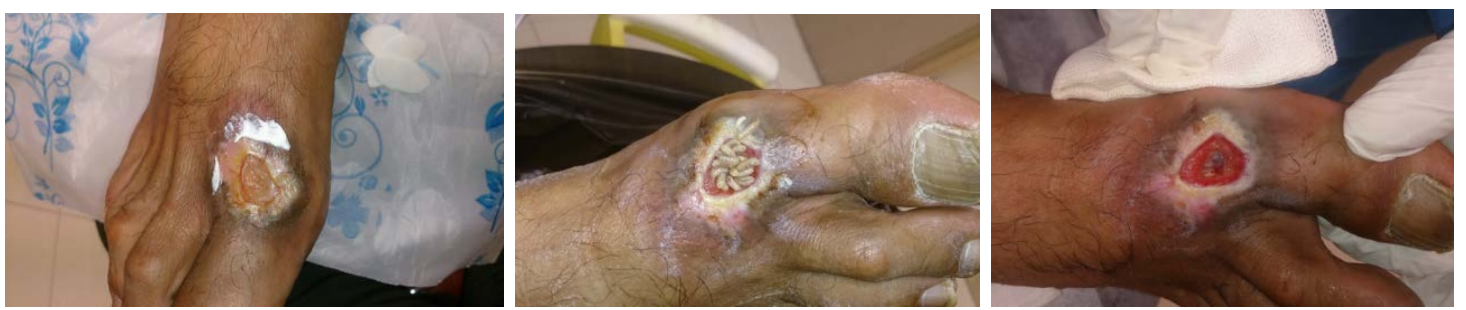

Figure 5. Diabetic foot ulcers in the right leg of a 55-year-old male, which have been treated with one round of maggot therapy in ACECR, Tehran, Iran (Original photos). 
Satisfaction of the patients and their relevant medical team was evaluated by a questionnaire. About $96.3 \%$ of the patients and physicians involved in our study were satisfied with the results of our new approach to the treatment of DFUs. Visual imagery of live larvae in wounds and social contacts in hospital/home atmosphere were the main factors that discouraged patients from undergoing the maggot therapy.

\section{DISCUSSION}

Most of the previous studies conducted on maggot therapy have focused on comparing of its efficacy with other routine treatments (4). On the other hand, the compatibility of maggot therapy with other DFU healing methods has become a frequent question among clinicians. In the present study, maggot therapy was added to routine treatment approaches as a complimentary therapy. There were no contradictions between maggot therapy and the other DFU healing methods used in this study.

The time interval for maggot therapy reapplication in each patient was 48 hours. To evaluate the efficacy of this new approach to maggot therapy, we calculated the active hours of larvae in the wounds and converted them to daily activities. In this regard, the duration for a significant reduction in the surface area of necrotic tissues was about four days. This finding is similar to that of many other studies (3), particularly the study of Sherman et al. who recorded a significant reduction in the size of diabetic wounds after one week following treatment with maggot therapy (16). Wang et al. also reported a reduced time of healing with maggot therapy compared to routine healing (19).

Lucilia sericata has been associated with nosocomial myiasis in Iran $(20,21)$. The presence of its larvae in human tissues confirms the diagnosis of myiasis, but the invasive behavior of this species is still debatable. However, some studies have shown that some strains of $L$. sericata can invade the healthy tissues (22). It has therefore been recommended that the safety and effectiveness of each $L$. sericata strain as medicinal agents for maggot therapy should be evaluated (23). The results of this study show that the Karaj Strain of L. sericata is safe and can effectively be used as agents of maggot therapy which can be recommended for importing as a medical product to the neighbouring countries.
Patients compliance is a global problem in maggot therapy $(24,25)$, mainly due to the disgusting feeling caused by the presence of live creatures such as worm-like larvae in the wounds. This can be expected from the ordinary people, but it is recommended that physicians encourage their clients to embrace maggot therapy because it is not an unusual picture in the medical sciences. Some healthcare professionals also avoid maggot therapy mainly due to the bad odor. Stinky smell produced during the process is due to the rupture of pyogenic abscesses at the wound site, and it seems to be a good sign of bacteria removal, which facilitates wound healing. Some of the physicians in Iran were reluctant to embrace maggot therapy because of lack of the approved national protocol.

Acceptability of maggot therapy by patients was $75 \%$ in a clinical trial conducted by Petherick et al. (24). Patient acceptance of maggot therapy did not vary with changing the method of application of larvae $(24,25)$. Maggot therapy acceptance rate was $77 \%$ in another study conducted by Spilsbury et al. (25). In the studies of Spilsbury and Patherick, the main factors for the refusal of maggot therapy were similar to those reported in our study. The main factor which affects maggot therapy acceptance is the visual appearance of larvae in wounds. In the present study, the acceptance rate of maggot debridement therapy among patients and their clinical team was about $96.3 \%$. Patients were highly satisfied with the results of the treatment approach.

\section{CONCLUSION}

In this study, we added maggot therapy to other routine methods of healing DFUs and demonstrated that this type of therapy can be added to conventional treatment approaches such as sharp debridement, antibiotic therapy and modern dressings to achieve a satisfactory results. We therefore recommend the application of maggot therapy as a complimentary therapy to other routine healing approaches. Finally, in our study, there was a very high degree of acceptance for this new approach to maggot therapy for healing DFUs, and most importantly, patients were very satisfied with the results of the treatment.

\section{Abbreviations}

ACECR: Academic Center for Education, Cul- 
ture and Research

TUMS: Tehran University of Medical Sciences

\section{Acknowledgement}

The authors wish to thank all personnel at ACECR wound clinic, Department of Medical
Entomology and Department of Medical Pathology at Tehran University of Medical Sciences (TUMS). This project was financially supported by TUMS with the research code of 96-01-27-34029. This study was a part of a project which was approved by Committee of Ethics in Medical Research at Tehran University of Medical Sciences with the code of ethics IR.TUMS.SPH.REC.1395.1533

\section{References}

1. World Health Organization. Global report on diabetes: executive summary 2017 [Available from:

http://apps.who.int/iris/bitstream/10665/204874/1/ WHO NMH NVI 16.3 eng.pdf.

2. Moxey P, Gogalniceanu P, Hinchliffe R, et al. Lower extremity amputations - a review of global variability in incidence. Diabet Med 2011;28(10):1144-53. https://doi.org/10.1111/j.1464-5491.2011.03279.x

3. Sun X, Jiang K, Chen J, et al. A systematic review of maggot debridement therapy for chronically infected wounds and ulcers. Int J Infect Dis 2014;25:32-7.

https://doi.org/10.1016/j.ijid.2014.03.1397

4. Zarchi K, Jemec GB. The efficacy of maggot debridement therapy-a review of comparative clinical trials. Int Wound J 2012;9(5):469-77. https://doi.org/10.1111/j.1742-481X.2011.00919.x

5. Marineau ML, Herrington MT, Swenor KM, Eron LJ. Maggot debridement therapy in the treatment of complex diabetic wounds. Hawaii Med J 2011;70(6):121-4.
6. Parnes A, Lagan KM. Larval therapy in wound management: a review. IntJ Clin Pract 2007;61(3):488-93.

7. Chernin E. Surgical maggots. South Med J 1986;79(9):1143-5.

8. Sherman RA, Pechter EA. Maggot therapy: a review of the therapeutic applications of fly larvae in human medicine, especially for treating osteomyelitis. Med Vet Entomol 1988;2(3):225-30. https://doi.org/10.1111/j.1365-2915.1988.tb00188.x

9. Sherman RA, Hall M, Thomas S. Medicinal maggots: an ancient remedy for some contemporary afflictions. Annu Rev Entomol 2000;45(1):55-81.

https://doi.org/10.1146/annurev.ento.45.1.55

10. shafee m. Bio-debridment of wounds. A thesis for PhD Degree. Baghyatallah university of medical scinces, 2006.

11. Falanga V. Wound Bed Preparation in Practice. EWMA Position Document. London: Medical Education Partnership Ltd; 2004. Wound bed preparation: Science applied to practice; pp. 2-5. 
12. Nishijima A, Gosho M, Yoshida R, et al. Effective wound bed preparation using maggot debridement therapy for patients with critical limb ischaemia. J Wound Care, 26(8):483-489. https://doi.org/10.12968/jowc.2017.26.8.483

13. Spessotto CV, Cavalli H, Eboni ACB, et al. Patients' satisfaction with and views about treatment with disease-modifying drugs in multiple sclerosis. Arq Neuro-psiquiatr 2016;74(8):617-20. http://dx.doi.org/10.1590/0004-282X20160091

14. Sen S, Fawson P, Cherrington G, et al. Patient satisfaction measurement in the disease management industry. Dis Manag 2005;8(5):288-300. https://doi.org/10.1089/dis.2005.8.288

15. Jain AKC. A new classification of diabetic foot complications: a simple and effective teaching tool. J Diab Foot Comp 2012;4(1):1-5.

16. Gottrup F, Jørgensen B. Maggot debridement: an alternative method for debridement. Eplasty. 2011;11.

17. Prete PE. Growth effects of Phaenicia sericata larval extracts on fibroblasts: mechanism for wound healing by maggot therapy. Life Sci 1997;60(8):505-10. https://doi.org/10.1016/S0024-3205(96)00688-1

18. Sherman RA. Maggot therapy for treating diabetic foot ulcers unresponsive to conventional therapy. Diabetes care 2003;26(2):446-51. https://doi.org/10.2337/diacare.26.2.446

19. Wang Sy, Wang Jn, Lv Dc, et al. Clinical research on the bio-debridement effect of maggot therapy or treatment of chronically infected lesions. Orthop Surg 2010;2(3):201-6. https://doi.org/10.1111/j.1757-7861.2010.00087.x

20. Alizadeh M, Mowlavi G, Kargar F, et al. A Review of Myiasis in Iran and a New Nosocomial Case from Tehran, Iran. J Arthropod-borne Dis 2014;8(2):124.

21. Yasin M. Ophthalmomyiasis and Basal Cell Carcinoma: A Case Report. Arch Clin Infect Dis $2014 ; 8(3): 1-3$

22. Cavuşoglu T, Apan T, Eker E, et al. Massive oculofacial myiasis infestation with Lucilia sericata. J Am Acad Dermatol 2009;61(1):169-70. https://doi.org/10.1016/j.jaad.2008.09.065

23. Sherman RA. Maggot therapy takes us back to the future of wound care: new and improved maggot therapy for the 21st century. J Diabetes Sci Technol 2009;3(2):336-44. https://doi.org/10.1177\%2F193229680900300215

24. Petherick ES, O'Meara S, Spilsbury K, et al. Patient acceptability of larval therapy for leg ulcer treatment: a randomised survey to inform the sample size calculation of a randomised trial. BMC Med Res Methodol 2006;6(1):43. https://doi.org/10.1186/1471-2288-6-43

25. Spilsbury K, Cullum N, Dumville J, et al. Exploring patient perceptions of larval therapy as a potential treatment for venous leg ulceration. Health Expect 2008;11(2):148-59. https://doi.org/10.1111/j.1369-7625.2008.00491.x 


\title{
Novi pristup terapiji larvama u lečenju ulkusa stopala
}

\author{
Omid Dehghan ${ }^{1}$, Seyed Mehdi Tabaie², Javad Rafinejad ${ }^{1}$, Mehrangiz Toutonnchy², \\ Amir Tiyuri ${ }^{3}$, Kamran Akbarzadeh ${ }^{4}$, Seyed Farzad Motevalli Haghi ${ }^{5}$ \\ ${ }^{1}$ Departman za medicinsku entomologiju i kontrolu vektora, Fakultet za javno zdravlje, \\ Univerzitet medicinskih nauka u Teheranu, Teheran, Iran \\ ${ }^{2}$ Departman za dermatologiju, Medicinski centar za laserska istraživanja, ACECR, Teheran, Iran \\ ${ }^{3}$ Departman za epidemiologiju, Fakultet za zdravlje, Iranski univerzitet medicinskih nauka, Teheran, Iran \\ ${ }^{4}$ Departman za medicinsku entomologiju i kontrolu vektora, Fakultet za javno zdravlje, \\ Univerzitet medicinskih nauka u Teheranu, Teheran, Iran \\ ${ }^{5}$ Departman za medicinsku entomologiju i kontrolu vektora, Istraživački centar za zdravstvene nauke, \\ Institut za lečenje zavisnosti, Fakultet za zdravlje, Univerzitet medicinskih nauka u Mazandaranu (Sari), Iran
}

\section{S AŽETAK}

Primena terapije larvama pokazala se delotvorno u lečenju komplikovanih ulkusa dijabetičkog stopala. Većina prethodnih studija fokusirala se na poređenje terapije larvama i rutinskih tretmana u lečenju ulkusa dijabetičkog stopala. Cilj ove studije bilo je priključivanje novog pristupa, terapije larvama, rutinskom lečenju. U ovoj studiji, osnovno očekivanje od terapije larvama bila je priprema rane za nastavak lečenja drugim merama. Studija je dizajnirana kao "before-after" opservaciona studija. Studija je uključila dvadeset pet od početnih četrdeset sedam volontera, koji su se na našoj klinici pojavili sa ulkusima dijabetičkog stopala. Ukupno dvadeset sedam bolesnika lečeno je terapijom larvama, pri čemu je korišćen Karaj soj Lucilia sericata (L. sericata). Terapija larvama priključena je rutinskom lečenju, kao komplementarna terapija. Tokom vremena, računata je površina nekrotičnog $i$ granulacionog tkiva. Zadovoljstvo bolesnika i lekara procenjivano je pomoću upitnika. Četiri dana od početka terapije larvama zabeleženo je značajno smanjenje u površini nekrotičnog tkiva, kao i povećanje granulacionog tkiva $(p<$ 0,0001). Nakon određivanja pridruženih varijabli, statistička analiza potvrdila je značajno smanjenje veličine nekrotičnog tkiva, kao i povećanje površine granulacionog tkiva $(\mathrm{p}<0,001)$. Oko $96,3 \%$ lekara i bolesnika, koji su učestvovali u ovoj studiji, bilo je zadovoljno rezultatima lečenja. Vreme, u kome je zabeleženo značajno smanjenje površine nekrotičnog tkiva, bilo je kraće nego u sličnim studijama.

Ova studija potvrdila je to da se efikasni, brzi i zadovoljavajući rezultati mogu dobiti kada se terapija larvama, kao komplementarna terapija u lečenju ulkusa dijabetičkog stopala, priključi rutinskom lečenju. Ovaj pristup može se uvesti kao novi modalitet u lečenju ulkusa dijabetičkog stopala, sa velikom stopom uspešnosti.

Ključne reči: terapija larvama, ulkusi dijabetičkog stopala, Lucilia sericata 